\title{
Recent advances in hydrogen peroxide imaging for biological applications
}

\author{
Hengchang Guo ${ }^{1,2^{*}}$, Hossein Aleyasin ${ }^{2,3}$, Bryan C Dickinson ${ }^{4}$, Renée E Haskew-Layton ${ }^{2,5}$ and Rajiv R Ratan²*
}

\begin{abstract}
Mounting evidence supports the role of hydrogen peroxide $\left(\mathrm{H}_{2} \mathrm{O}_{2}\right)$ in physiological signaling as well as pathological conditions. However, the subtleties of peroxide-mediated signaling are not well understood, in part because the generation, degradation, and diffusion of $\mathrm{H}_{2} \mathrm{O}_{2}$ are highly volatile within different cellular compartments. Therefore, the direct measurement of $\mathrm{H}_{2} \mathrm{O}_{2}$ in living specimens is critically important. Fluorescent probes that can detect small changes in $\mathrm{H}_{2} \mathrm{O}_{2}$ levels within relevant cellular compartments are important tools to study the spatial dynamics of $\mathrm{H}_{2} \mathrm{O}_{2}$. To achieve temporal resolution, the probes must also be photostable enough to allow multiple readings over time without loss of signal. Traditional fluorescent redox sensitive probes that have been commonly used for the detection of $\mathrm{H}_{2} \mathrm{O}_{2}$ tend to react with a wide variety of reactive oxygen species (ROS) and often suffer from photostablilty issues. Recently, new classes of $\mathrm{H}_{2} \mathrm{O}_{2}$ probes have been designed to detect $\mathrm{H}_{2} \mathrm{O}_{2}$ with high selectivity. Advances in $\mathrm{H}_{2} \mathrm{O}_{2}$ measurement have enabled biomedical scientists to study $\mathrm{H}_{2} \mathrm{O}_{2}$ biology at a level of precision previously unachievable. In addition, new imaging techniques such as two-photon microscopy (TPM) have been employed for $\mathrm{H}_{2} \mathrm{O}_{2}$ detection, which permit real-time measurements of $\mathrm{H}_{2} \mathrm{O}_{2}$ in vivo. This review focuses on recent advances in $\mathrm{H}_{2} \mathrm{O}_{2}$ probe development and optical imaging technologies that have been developed for biomedical applications.
\end{abstract}

Keywords: Hydrogen peroxide $\left(\mathrm{H}_{2} \mathrm{O}_{2}\right)$, Reactive oxygen species (ROS), Molecular imaging, Fluorescent probe, Nanoparticles, Two-photon microscopy, Ratiometric imaging, Fluorescence lifetime imaging microscopy (FLIM), Chemiluminescence

\section{Introduction}

The role of $\mathrm{H}_{2} \mathrm{O}_{2}$ as a second messenger, in regulating fundamental biological processes, has been identified not long ago and is increasingly supported by new data [1-7]. $\mathrm{H}_{2} \mathrm{O}_{2}$ is involved in therapeutic processes such as wound healing, anti-bacterial defense, stem cell proliferation, and an adaptive response in astrocytes that leads to neuronal protection [1,5-10]. However, over-production of $\mathrm{H}_{2} \mathrm{O}_{2}$ exerts toxic effects on the cell and its surrounding environment. The aberrant production of $\mathrm{H}_{2} \mathrm{O}_{2}$ within cellular compartments is connected to serious pathological conditions such as cancer [11], ageing [12-14], diabetes [15], and neurodegenerative diseases [16-18].

\footnotetext{
*Correspondence: hcguo2012@gmail.com; rrr2001@med.cornell.edu ${ }^{1}$ Fischell Department of Bioengineering, University of Maryland, College Park, MD 20742, USA

${ }^{2}$ Burke Medical Research Institute, Weill Medical College of Cornell University, White Plains, NY 10605, USA

Full list of author information is available at the end of the article
}

A substantial challenge in elucidating the diverse roles of $\mathrm{H}_{2} \mathrm{O}_{2}$ in complex biological environments is measuring the spatial and temporal dynamics of this reactive oxygen metabolite. Much of the data implicating $\mathrm{H}_{2} \mathrm{O}_{2}$ both pathological and physiological roles in cultured cells and in vivo has been acquired using treatment with exogenous $\mathrm{H}_{2} \mathrm{O}_{2}[19,20]$, over expression of hydroperoxide inducing enzymes or $\mathrm{H}_{2} \mathrm{O}_{2}$ lysing/scavenging agents $[1,21]$, or tampering with ROS production cellular machinery such as NADPH oxidase (Nox) expressing cells [22]. Although these studies were critical in establishing crucial biological roles of $\mathrm{H}_{2} \mathrm{O}_{2}$, a key to fully understanding the mechanistic bases of redox biology is measuring the amount of $\mathrm{H}_{2} \mathrm{O}_{2}$ generated in specific intracellular compartments.

Traditional approaches to measuring $\mathrm{H}_{2} \mathrm{O}_{2}$ in living systems suffer from several issues: 1) The probes are often nonspecific and react with other reactive oxygen species such as hydroxyl radicals and superoxide, as well 
as reactive nitrogen species. 2) $\mathrm{H}_{2} \mathrm{O}_{2}$ is generally produced at a low concentration and can have a short halflife due to the activity of enzymes that neutralize it. 3) $\mathrm{H}_{2} \mathrm{O}_{2}$ is often produced in specific cellular compartments and rapidly diffuses across the membranes. For example, dichlorofluorescein (DCF), which has served as the workhorse for the redox biology community, detects multiple types of reactive small molecules, such as superoxide $\left(\mathrm{O}_{2}{ }^{-}\right)$, hydroperoxy radical $\left(\mathrm{HO}_{2}{ }^{\circ}\right)$, singlet oxygen $\left({ }^{1} \mathrm{O}_{2}\right)$, peroxy radical $\left(\mathrm{RO}_{2}{ }^{\circ}\right)$. DCF is not an ideal tool to determine the localization of $\mathrm{H}_{2} \mathrm{O}_{2}$ production. In addition to this lack of specificity of DCF for $\mathrm{H}_{2} \mathrm{O}_{2}$ detection, it can directly result in the creation of further ROS and thiol oxidation when exposed to UV radiation, and interacts with cytochrome c, rather than ROS as a consequence of apoptosis [23-25]. To overcome the aforementioned disadvantages for detecting ROS, recent efforts have aimed at 1) increasing the selectivity for $\mathrm{H}_{2} \mathrm{O}_{2}$ detection over related ROS, particularly superoxide, nitric oxide, and hydroxyl radical and 2) improving photostability and determining the localization of $\mathrm{H}_{2} \mathrm{O}_{2}$ production. Recently, specific and highly sensitive fluorescent $\mathrm{H}_{2} \mathrm{O}_{2}$ probes have been developed to circumvent these issues, including chemoselective fluorescent probes, fluorescent proteins, and nanoparticles [26,27].

Confocal microscopy coupled with chemoselective fluorescent reporters permits the imaging of localized intracellular $\mathrm{H}_{2} \mathrm{O}_{2}$ levels. However, due to scattering and tissue penetration, imaging $\mathrm{H}_{2} \mathrm{O}_{2}$ levels in whole organisms often requires deep tissue imaging techniques. For example, two-photon microscopy (TPM) $[25,28]$ and photoluminescence can permit thick tissue imaging and in vivo studies [29,30].

In this review, we describe and compare various methodologies for detection and imaging of $\mathrm{H}_{2} \mathrm{O}_{2}$ production in cells and whole organisms.

\section{Fluorescent probes for $\mathrm{H}_{2} \mathrm{O}_{2}$ imaging Small-molecule fluorescent probes}

Small-molecule fluorescence probes for $\mathrm{H}_{2} \mathrm{O}_{2}$ are generally based on the oxidation-reduction processes between the $\mathrm{H}_{2} \mathrm{O}_{2}$ and reduced probe, which fluoresces upon oxidation. Several novel fluorescent probes capable of detecting $\mathrm{H}_{2} \mathrm{O}_{2}$ with high selectivity have been reported, and some of them have been used to monitor intracellular $\mathrm{H}_{2} \mathrm{O}_{2}$. A comprehensive list of fluorescent $\mathrm{H}_{2} \mathrm{O}_{2}$ probes is listed in Table 1.

One approach for the development of $\mathrm{H}_{2} \mathrm{O}_{2}$-selective probes utilizes a boronate-deprotection mechanism $[2-4,31,38,42,45]$. Figure 1 that displays the mechanism of hydrogen peroxide-mediated fluorescent enhancement and several example structures of fluorescent probes based on this mechanism. This detection strategy relies on the selective $\mathrm{H}_{2} \mathrm{O}_{2}$-mediated transformation of arylboronates to phenols. Arylboronates are appended to profluorescent molecules, such that reaction with $\mathrm{H}_{2} \mathrm{O}_{2}$ generates a fluorescent product. The monoboronate-based family of probes (PF-1, PF-2, PF-3, PO1, and PY1) can detect physiological changes in endogenous $\mathrm{H}_{2} \mathrm{O}_{2}$ levels. Since a wide color palette of such probes has been developed, various combinations can be selected for multicolor imaging experiments. The addition of acetoxymethyl ester-protected pro-anionic groups gives rise to the dye peroxyfluor-6 acetoxymethyl ester (PF6-AM), which increases cellular retention and further increases sensitivity to $\mathrm{H}_{2} \mathrm{O}_{2}$ [2,25]. Although boronate-deprotection-based probes have improved $\mathrm{H}_{2} \mathrm{O}_{2}$ localization studies, quantitative analysis of $\mathrm{H}_{2} \mathrm{O}_{2}$ generation using fluorescent probes is still challenging. Specifically, the signal from the single-wavelength emitting probes can be affected by the concentration of the probe. To address this, a monoboronate-based probe was synthesized, Ratio Peroxyfluor 1 (RPF)-1 that provides a ratiometric change of two fluorescent signals upon reaction with $\mathrm{H}_{2} \mathrm{O}_{2}$, which can potentially permit normalization to probe concentration [36]. Because peroxynitrite has also been shown to react with boronates to create a fluorescent product [52], it is critical to perform proper controls when using a boronate-based fluorescent probe, such as expression of catalase or using a peroxynitite-specific probe.

Combining the boronate-based probe strategy with organelle-targetable functional groups has provided probes that can measure $\mathrm{H}_{2} \mathrm{O}_{2}$ levels with spatial resolution. In particular, several mitochondria-targeted probes have been generated, including Mitochondrial Peroxy Yellow 1 (MitoPY1) and SHP-Mito [25,42,43,51], which utilize a positively charged phosphonium moiety for mitochondrial targeting. MitoPY1 and SHP-Mito can both be utilized as two-photon imaging probes [25,51]. Nuclear Peroxy Emerald (NucPE) 1 is nuclear-localized fluorescent probe that utilizes a boronate protecting group to measure nuclear $\mathrm{H}_{2} \mathrm{O}_{2}$ levels, which has been shown to function in vivo [45].

All of the boronate-based probes react irreversibly with $\mathrm{H}_{2} \mathrm{O}_{2}$, meaning the fluorescent signal is based on the accumulated $\mathrm{H}_{2} \mathrm{O}_{2}$ generated. By contrast, Redoxfluor (RF)-1 uses a reversible disulfide-based redox sensing mechanism, allowing multiple reversible redox reactions in the cellular environment to be detected over time [41]. However, one disadvantage is that RF-1 is not selective for one particular ROS.

One limitation of ROS fluorescent probes is their application in in vivo studies. The visible light excitation affects probe photobleaching, tissue and organ penetration, and subsequent imaging detection. To tackle these issues, Peroxy Caged Luciferin (PCL)-1 and near-infrared (NIR) probe quinone Cy-7 (QCy7) were developed [30,47,49]. PCL-1 and PCL-2 are prosubstrates for luciferase and have 
Table 1 Small molecule probes for $\mathrm{H}_{2} \mathrm{O}_{2}$ imaging

\begin{tabular}{|c|c|c|c|c|c|c|}
\hline \multicolumn{2}{|c|}{ Fluorescent probes } & \multirow{2}{*}{$\begin{array}{l}\text { Excitation/Emission } \\
(\mathrm{nm})\end{array}$} & \multicolumn{3}{|l|}{ Additional features } & \multirow[t]{2}{*}{ References } \\
\hline Abbreviation & Full name & & Detection mechanism & Intra-cellular & In vivo & \\
\hline PX-1 & Peroxyxanthone-1 & $350 / 440$ & Boronate-deprotection mechanism & Yes & N/A & [31] \\
\hline $\mathrm{FP}-\mathrm{H} 2 \mathrm{O} 2-\mathrm{NO}$ & N/A & $400 / 460$ & Response to $\mathrm{H}_{2} \mathrm{O}_{2}, \mathrm{NO}$, or both & Yes & N/A & [32] \\
\hline DMACA & N/A & $400 / 484,566$ & Ratiometric imaging & Yes & N/A & [33] \\
\hline DPPEA-HC & 7-hydroxy-2-oxo-N-(2-(diphenylphosphino)ethyl)-2H-chromene-3-carboxamide & $403 / 449$ & PET control & N/A & N/A & [34] \\
\hline PL-1 & Peroxy Lucifer 1 & $410 / 475,540$ & $\begin{array}{l}\text { Boronate-deprotection mechanism; } \\
\text { Ratiometric imaging }\end{array}$ & Yes & N/A & {$[35]$} \\
\hline RPF-1 & Ratio Peroxyfluor 1 & $420 / 464,517$ & $\begin{array}{l}\text { Boronate-deprotection mechanism; } \\
\text { Ratiometric imaging }\end{array}$ & N/A & N/A & {$[36]$} \\
\hline PF-1 & Peroxyfluor-1 & $450 />460$ & Boronate-deprotection mechanism & Yes & N/A & {$[31,37]$} \\
\hline PF-2 & Peroxyfluor-2 & $475 / 511$ & Boronate-deprotection mechanism & Yes & Yes & {$[25,38,39]$} \\
\hline PF6-AM & Peroxyfluor-6 acetoxymethyl ester & $482 / 517$ & $\begin{array}{l}\text { Boronate-deprotection mechanism; } \\
\text { High cellular permeability }\end{array}$ & Yes & N/A & {$[2,25,28]$} \\
\hline NBzF & N/A & $490 / 525$ & PET control & Yes & N/A & [40] \\
\hline PF-3 & Peroxyfluor-3 & $492 / 515$ & Boronate-deprotection mechanism & Yes & N/A & [38] \\
\hline RF-1 & Redoxfluor 1 & $495 / 503$ & Boronate-deprotection mechanism & Yes & N/A & [41] \\
\hline MitoPY1 & Mitochondrial Peroxy Yellow 1 & $510 / 528$ & $\begin{array}{l}\text { Boronate-deprotection mechanism; } \\
\text { Mitochondria-targeted }\end{array}$ & Yes & N/A & {$[25,42,43]$} \\
\hline PY1-ME & Peroxy Yellow 1 Methyl-Ester & $515 / 540$ & Boronate-deprotection mechanism & Yes & N/A & [44] \\
\hline (NucPE) 1 & Nuclear Peroxy Emerald 1 & $514 / 540$ & $\begin{array}{l}\text { Boronate-deprotection mechanism; } \\
\text { Nuclear localized }\end{array}$ & Yes & Yes & [45] \\
\hline PY1 & Peroxy Yellow 1 & $519 / 548$ & Boronate-deprotection mechanism & Yes & N/A & {$[25,38]$} \\
\hline PO1 & Peroxy Orange 1 & $540 / 565$ & Boronate-deprotection mechanism & Yes & N/A & {$[25,38]$} \\
\hline Amplex Red & Amplex Red & $571 / 581$ & Conjunction with horseradish peroxidase & N/A & Yes & {$[1,46]$} \\
\hline PR-1 & Peroxy Red 1 & $\sim 575 / 585$ & Boronate-deprotection mechanism & Yes & N/A & [31] \\
\hline PCL-1 & Peroxy Caged Luciferin 1 & NA/612 & $\begin{array}{l}\text { Boronate-deprotection mechanism; } \\
\text { Bioluminescence imaging }\end{array}$ & N/A & Yes & {$[30,47]$} \\
\hline PCL-2 & Peroxy Caged Luciferin 2 & & $\begin{array}{l}\text { Boronate-deprotection mechanism; } \\
\text { Bioluminescence imaging }\end{array}$ & N/A & Yes & {$[48]$} \\
\hline QCy7 & Quinone Cy-7 & $595 / 635$ & Cyanine-based probe & N/A & Yes & [49] \\
\hline PN1 & Peroxy Naphthalene 1 & TPM750nm & Boronate-deprotection mechanism & N/A & Yes & [50] \\
\hline SHP-Mito & N/A & TPM750nm & $\begin{array}{l}\text { Boronate-deprotection mechanism } \\
\text { Mitochondria-targeted }\end{array}$ & Yes & Yes & [51] \\
\hline
\end{tabular}




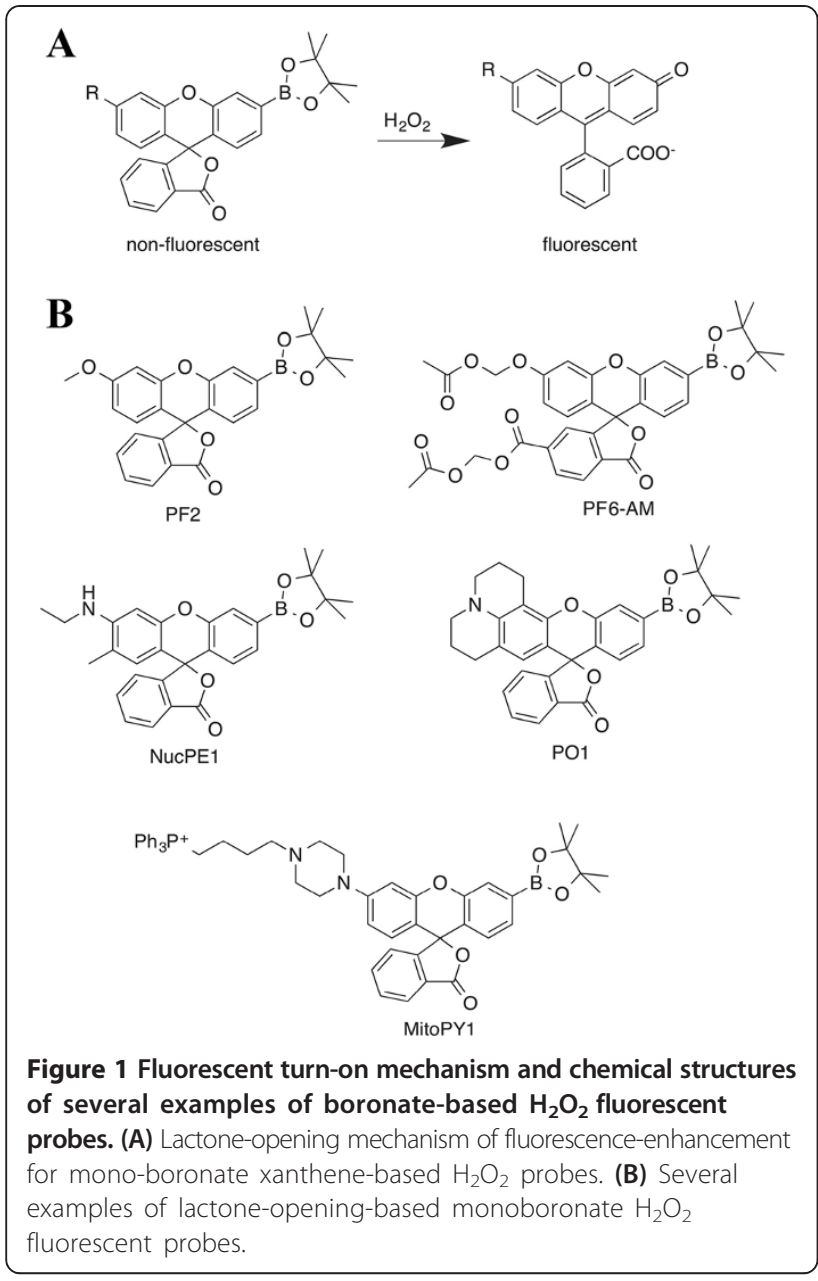

been utilized for noninvasive in vivo $\mathrm{H}_{2} \mathrm{O}_{2}$ detection throughout whole mice $[30,47,48]$. NIR imaging of the Cy7 is another attractive tool in animal studies due to the deep penetration of the NIR photons and low background fluorescence of the tissue. QCy7 enabled monitoring $\mathrm{H}_{2} \mathrm{O}_{2}$ signaling upon injection of lipopolysaccharides (LPS) into mice [49].

\section{Nanoprobes}

Compared with small-molecule fluorescent probes, nanoparticles offer several advantages [53,54]: (1) Nanoparticles often have stronger fluorescent emission due to large number of molecular probes loaded in each single nanoprobe. (2) The high surface-area-over-volume ratio provides a higher probability for analyte detection. (3) Encapsulating small molecule fluorescent probes into nanoparticles can improve their stability. (4) The nanoparticle often serves as a protecting device for the sensory contents, protection from external interference present in biological environments (e.g., undesirable enzymatic reactions and nonspecific uptake by proteins). (5) Nanoprobes can possess multifunctionality, and target- specificity by conjugating ligand moieties onto the nanoparticle surface.

A number of nanoprobes were listed in Table 2 . Peroxalate-based nanoparticles were recently developed which chemically excites the encapsulated dye, leading to light emission from the nanoparticles and the imaging of $\mathrm{H}_{2} \mathrm{O}_{2}$ [29,55-57]. Encapsulating fluorescent probes into nanoparticles can improve their stability. This nanoprobe was recently demonstrated by Lee et al. for in vivo imaging of global $\mathrm{H}_{2} \mathrm{O}_{2}$ in mouse model [29]. Semiconducting polymer-based nanoprobe CF-SPN has another advantage that combines chemiluminescence imaging with ratiometric imaging for liver-targeted detection of ONOOand $\mathrm{H}_{2} \mathrm{O}_{2}$ simultaneously in the liver of living mice and in real time [58]. This nanoprobe demonstrated multifunctionality chemiluminescence imaging and ratiometric imaging for ROS sensing. For high sensitivity single-molecule detection, single-walled carbon nanotube (SWNT) embedded nanosensor exhibited high selectivity and sensitivity to single molecules of $\mathrm{H}_{2} \mathrm{O}_{2}$ [59-61], which raises the potential for a hitherto unseen level of specificity in redox signaling analysis.

\section{Genetic fluorescent proteins}

In the past, researchers have largely relied on the use of fluorescent dyes for ROS sensing due to their good sensitivity, high signal-to-noise ratio, cell permeability, and ease of measurement. The emerging genetic fluorescent proteins offer another option for high resolution selective $\mathrm{H}_{2} \mathrm{O}_{2}$ imaging. Allowing a dynamic measurement for the reversible detection of $\mathrm{H}_{2} \mathrm{O}_{2}$, Belousov, et al. developed a group of genetically encoded fluorescent proteins HyPer and their mutants to enable transient live-cell imaging [6,70-75]. It is a ratiometric fluorescent indicator of $\mathrm{H}_{2} \mathrm{O}_{2}$ in which cpYFP is inserted into the regulatory domain of an Escherichia coli peroxide sensor OxyR [71]. HyPer is able to detect nanomolar concentrations of $\mathrm{H}_{2} \mathrm{O}_{2}$ in vitro, to micromolar levels of $\mathrm{H}_{2} \mathrm{O}_{2}$ exogenously added to cells, or changes of intracellular $\mathrm{H}_{2} \mathrm{O}_{2}$ upon growth factor stimulation [71]. Due to genetic labeling, the HyPer family of genetically encoded fluorescent proteins have been successfully targeted to several cellular compartments such as the nucleus, cytosol, peroxisomes, mitochondria and the endoplasmic reticulum [70]. Thereby they allow for the intracellular spatial monitoring of $\mathrm{H}_{2} \mathrm{O}_{2}$ production, which can further improve $\mathrm{H}_{2} \mathrm{O}_{2}$ imaging with high signal-to-background noise from tissue autofluorescence in biological systems. HyPer probes are $\mathrm{pH}$ sensitive. To address this issue $\mathrm{pH}$-specific probes are used as controls. HyPer-C199S would be an ideal control as a $\mathrm{pH}$-sensitive and $\mathrm{H}_{2} \mathrm{O}_{2}$-insensitive version [76].

To improve the dynamic range of half-oxidation and half-reduction responses, HyPer-2 and HyPer-3 were developed which shows an expanded dynamic range. HyPer-3 
Table 2 Nanoparticles for $\mathrm{H}_{2} \mathrm{O}_{2}$ detection

\begin{tabular}{|c|c|c|}
\hline Nanoparticles & Detection features & References \\
\hline Peroxalate nanoparticles & Chemiluminescence imaging & {$[29,55-57]$} \\
\hline FPOC NPS & Chemiluminescence imaging; & [62] \\
\hline CF-SPN & Chemiluminescence imaging; Ratiometric imaging & [58] \\
\hline $\mathrm{TiO}_{2}$ nanorods & Confocal microscopy; HRP-catalyzed oxidation & [63] \\
\hline NanoPEBBLE & Confocal microscopy; Hydrophobic Ormosil Nanoparticles & [64] \\
\hline HRP-loaded PEG hydrogel spheres & Fluorescence imaging; Oxidized fluorophores such as Amplex Red becoming fluorescence. & [65] \\
\hline SWNT & Photoluminescence detection; Single molecule sensitivity & [59-61] \\
\hline $\mathrm{Fe}_{3} \mathrm{O}_{4}$ & Magnetic Nanoparticles & {$[66,67]$} \\
\hline Gold (Au) Nanodot & Luminescence quenching & [68] \\
\hline Cyclometalated Iridium(III) & Phosphorescent probe & [69] \\
\hline
\end{tabular}

showed faster oxidation-reduction kinetics and a higher fluorescence ratio (F500/F420) than what was reported for HyPer, demonstrating its advantage for $\mathrm{H}_{2} \mathrm{O}_{2}$ detection [77]. Both HyPer and HyPer-3 are applicable for fluorescence lifetime imaging microscopy (FLIM).

Redox-sensitive GFP (roGFP) [72,73] coupled with yeast $\mathrm{H}_{2} \mathrm{O}_{2}$-sensing signaling peroxidase Orp1 [78] is a genetically encoded $\mathrm{H}_{2} \mathrm{O}_{2}$ sensor that has been used to detect and quantify physiological levels of $\mathrm{H}_{2} \mathrm{O}_{2}$ in vivo. In roGFP2Orp1, Orp1 relays a disulfide bridge to redox-sensitive GFP (roGFP). The redox equilibrium of the engineered cysteines is associated with measurable ratiometric fluorescent changes. Contrary to HyPer probes, this redox-dependent fluorescence is insensitive to $\mathrm{pH}$ changes in the physiological range. RoGFP2-Orp1 has been successfully used to measure physiologically relevant changes in $\mathrm{H}_{2} \mathrm{O}_{2}$ levels in Drosophila tissues and in living larvae by real-time imaging [79-81].

\section{Optical imaging of $\mathrm{H}_{2} \mathrm{O}_{2}$ in biological system Confocal microscopy}

Confocal microscopy uses a scanning laser beam that is focused on the sample for imaging, with a pinhole placed in front of the detector. Confocal microscopy increases optical resolution and contrast by using a pinhole that prevents the out-of-focus photons from reaching the detector. It is the most popular imaging technique for $\mathrm{H}_{2} \mathrm{O}_{2}$ detection ex vivo. Most fluorescent probes were developed for confocal microscopy. However, confocal microscopy has limitations, such as optical scattering, photodamage,
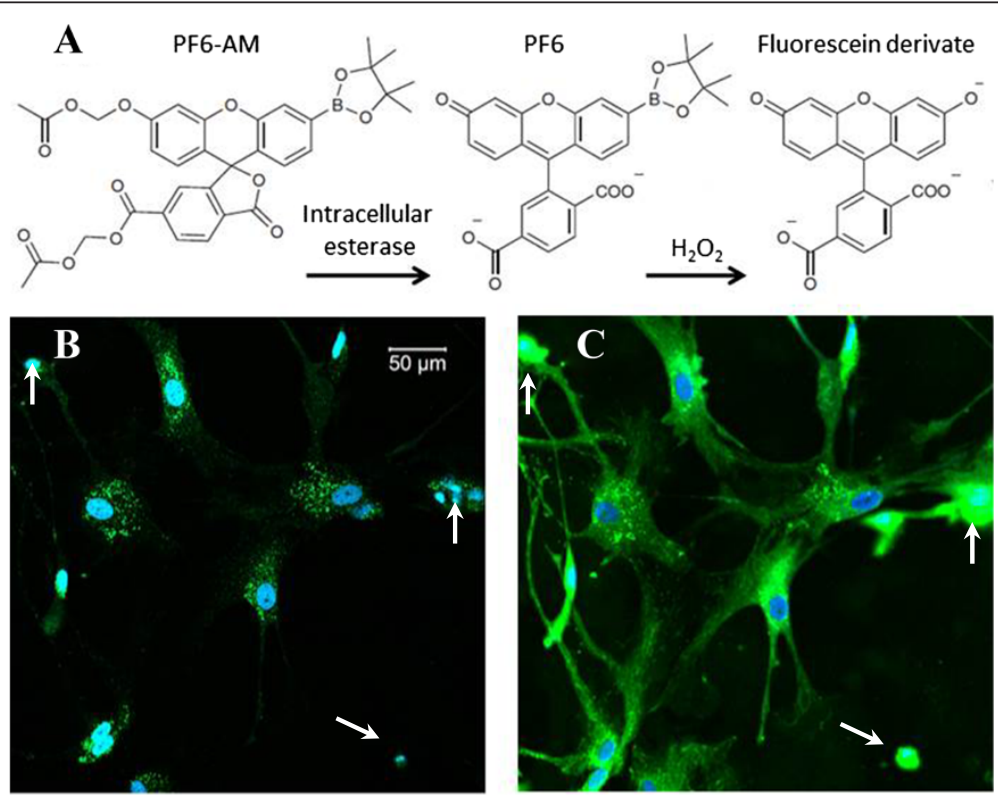

Figure 2 Fluorescence imaging of intracellular $\mathrm{H}_{2} \mathrm{O}_{2}$ production using fluorescence probe PF6-AM (green). (A) Mechanism of Chemoselective $\mathrm{H}_{2} \mathrm{O}_{2}$ PF6-AM. (B) TPF imaging of $\mathrm{H}_{2} \mathrm{O}_{2}$ in astrocytes, fluorescence excited with a $770 \mathrm{~nm}$ Ti:sapphire laser. (C) Confocal microscopy of $\mathrm{H}_{2} \mathrm{O}_{2}$ in same astrocytes imaged in panel B, fluorescence excited with a $488 \mathrm{~nm}$ laser. The nuclei were stained with Hoechst 33342 (blue). 


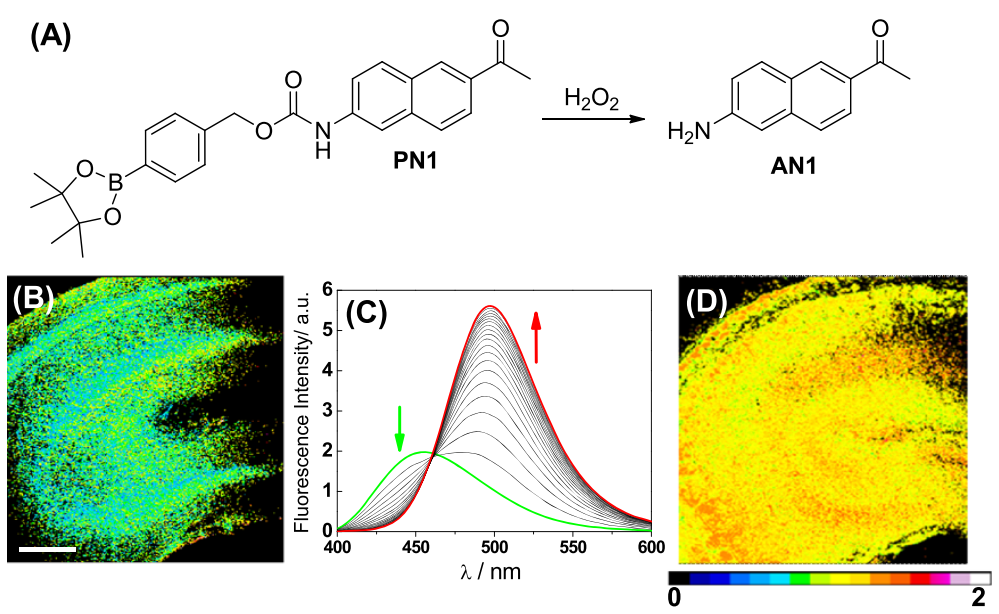

Figure 3 Ratiometric imaging of fresh rat hippocampal slice treated with $\mathbf{H}_{\mathbf{2}} \mathrm{O}_{2}$. (A) The reaction between PN1 and $\mathrm{H}_{2} \mathrm{O}_{2}$ produced AN1 as the only major fluorescent product. (B) A hippocampal slice labeled with PN1. (C) Fluorescence spectra responses of $3 \mu \mathrm{M} P \mathrm{PN}$ to $1 \mathrm{mM} \mathrm{H} \mathrm{H}_{2}$. Spectra were acquired at 0, 10, 20, 30, 40, 50, 60, and 120 min after $\mathrm{H}_{2} \mathrm{O}_{2}$ was added. (D) A hippocampal slice labeled with PN1 after pretreated with $\mathrm{H} 2 \mathrm{O} 2$. Scale bars: $30 \mu \mathrm{m}$. The figures were adapted from ref. [50] with permission.

photobleaching, and limited imaging depth for use in real time in vivo studies. Furthermore, prolonged visible light exposure can result in artifactual ROS generation and signal amplification [82].

The recent advance of in vivo confocal microscopy is based on microendoscopy. By utilizing a miniprobe for confocal microendoscopy, PY1 was demonstrated for in vivo $\mathrm{H}_{2} \mathrm{O}_{2}$ imaging in colorectal cancer [83].

\section{Two-photon microscopy}

TPM provides sub-micron resolution imaging with lower phototoxicity and deeper tissue penetration than confocal microscopy [28]. In the two-photon process, a molecule simultaneously absorbs two photons whose individual energy is only half of the energy needed to excite that molecule, and then releases the energy to an emission photon. The main differences between confocal microscopy and TPM are the excitation light source and the fluorescence detection unit. TPM, including all commercial versions, is typically implemented in a laser scanning microscope equipped with a NIR ultrafast pulse laser.

TPM was demonstrated for imaging intracellular $\mathrm{H}_{2} \mathrm{O}_{2}$ production in live cells and tissues [25,35,50,51]. Figure 2 shows TPM imaging of intracellular $\mathrm{H}_{2} \mathrm{O}_{2}$ in rat primary astrocytes using the chemoslective fluorescence probe PF6-AM. Figure 2A shows the $\mathrm{H}_{2} \mathrm{O}_{2}$ imaging mechanism of trappable probe PF6-AM [2]. Figure 2B shows TPM imaging of intracellular $\mathrm{H}_{2} \mathrm{O}_{2}$. As a comparison, Figure $2 \mathrm{C}$ shows confocal microscopy of the same cells using a $488 \mathrm{~nm}$ argon laser with the same fluorescence detection. Three arrows indicate strong light scattering in the same cells in Figure 2C. The TPM imaging here demonstrated the advantages of low scattering and low background noise.
For the deep tissue in vivo TPM, it has motivated new trends of technology development including long wavelength lasers [84-88], fast scanner [89,90], and microendoscopes [91-93]. These techniques may further extend in vivo TPM for deep tissue $\mathrm{H}_{2} \mathrm{O}_{2}$ imaging in real time.

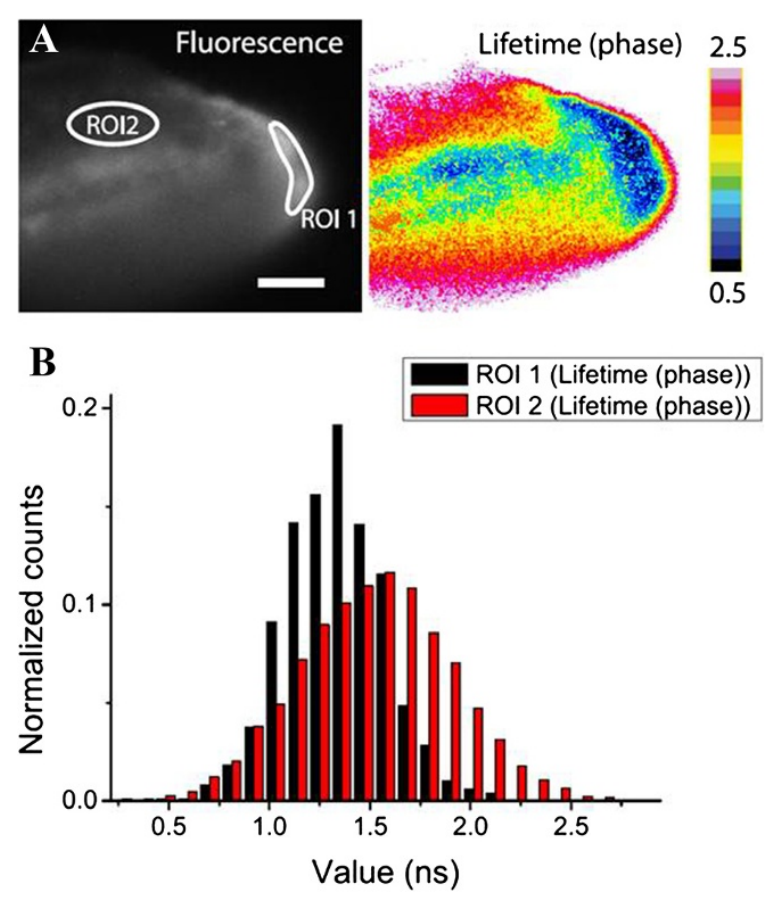

Figure 4 FLIM of HyPer-3 response to $\mathrm{H}_{2} \mathrm{O}_{2}$ production induced by inflammation in zebrafish larvae. (A) Left and right panels represent fluorescence intensity and FLIM images, respectively. ROI1 highlights the wound margin; $\mathrm{RO} 2$ represents an area distant from the wound. (B) Fluorescence lifetime distribution plot for ROI1 and ROI2 in panel A. The figures were adapted from ref. [77] with permission. 


\section{Ratiometric imaging}

Ratiometric imaging is the division of one fluorescence channel by another one to derive the ratiometric channel. Ratiometric imaging has been widely used to detect intracellular ion concentrations, protein distributions, voltage or $\mathrm{pH}$ changes [94]. Compared to traditional fluorescence intensity imaging, ratiometric imaging relies on measuring a shift in emission instead of merely a change in intensity. It is extremely attractive for quantitative analysis because it corrects for unequal fluorophore labeling and photobleaching. Dual wavelength excitation/detection is the key for measuring emission shifts and intensity changes of fluorophores. The recent development of ratiometric $\mathrm{H}_{2} \mathrm{O}_{2}$ probes have been used for ratiometric imaging based on wide-field microscopy, confocal microscopy and TPM [35,50,51,71,77,94-96].

Figure 3 shows TPM ratiometric image of a fresh rat hippocampal slice treated with $\mathrm{H}_{2} \mathrm{O}_{2}$ production. This imaging technique provides a solution for deep tissues $\mathrm{H}_{2} \mathrm{O}_{2}$ quantitative analysis.

\section{FLIM}

FLIM is an optical imaging technique based on the differences in the exponential decay rate of the fluorescence from a fluorescent sample $[97,98]$. Because fluorescence lifetime $\tau$ is independent of indicator concentration, FLIM measurement is essentially insensitive to indicator expression level, non-uniform distribution, and partial photobleaching. FLIM generates absolute quantitative readouts while requiring only a single-wavelength excitation, provided that the indicator is calibrated in situ (e.g., in permeablized cells) or in vitro under conditions closely resembling intracellular environments. Figure 4 shows inflammation driven $\mathrm{H}_{2} \mathrm{O}_{2}$ production in zebra fish larvae using representative FLIM of HyPer-3 [77]. The pattern of the fluorescence lifetime changes indicated the gradient of $\mathrm{H}_{2} \mathrm{O}_{2}$ with higher concentrations of the oxidant at the wounding site. This imaging technique provides another solution for $\mathrm{H}_{2} \mathrm{O}_{2}$ quantitative analysis.

\section{Chemi-/bioluminescence imaging}

In vivo chemi-/bioluminescence imaging is a popular method to monitor enzymatic light emission by a living organism [99-101]. The detection signal is generally from red to near-infrared (NIR) light that offers deep depth imaging of $\mathrm{H}_{2} \mathrm{O}_{2}$ in organs. By using cooled charge-coupled device (CCD) cameras, this optical imaging modality gets high sensitive. The field of view is up to scores of centimeter
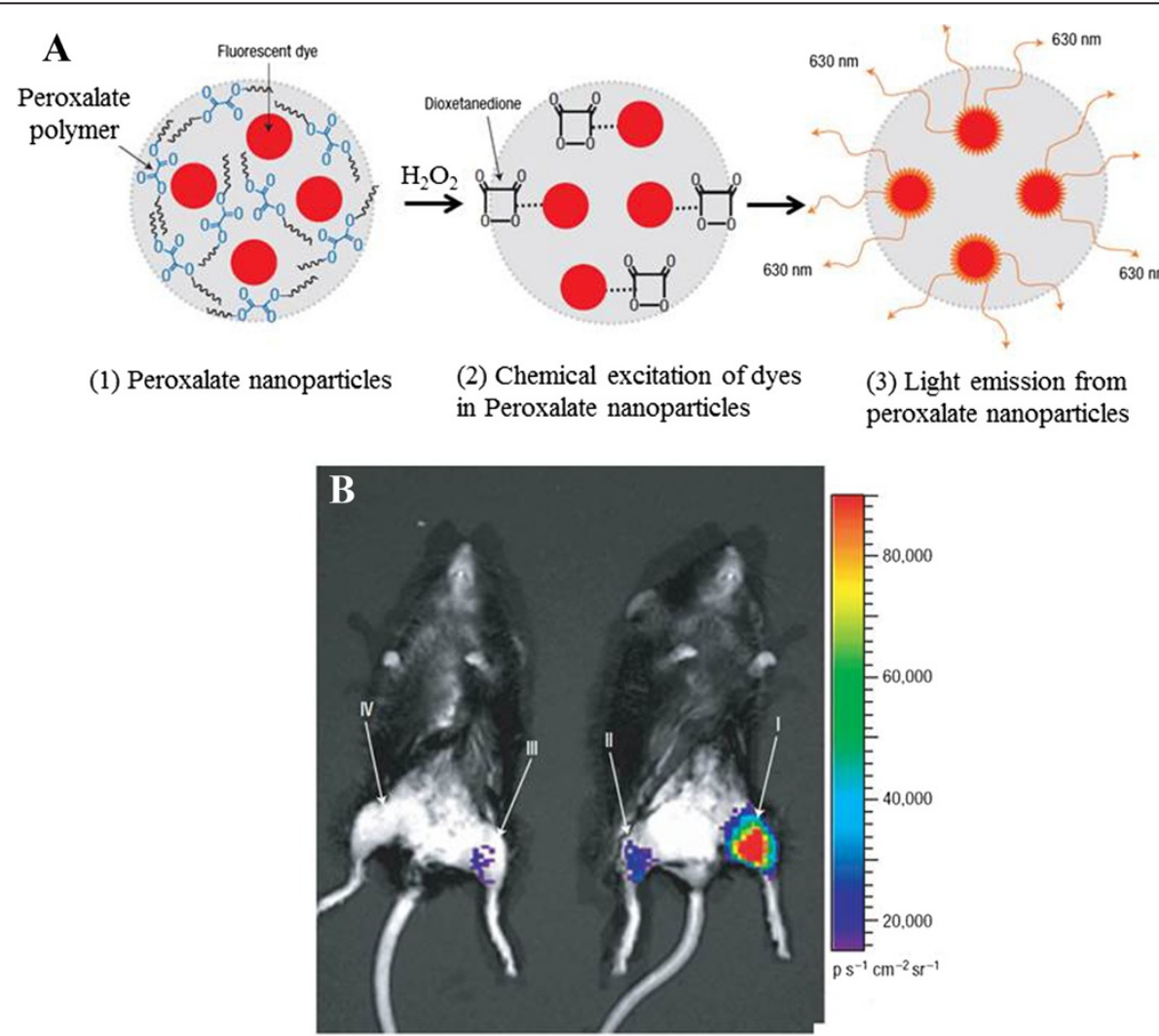

Figure 5 In vivo imaging of $\mathrm{H}_{2} \mathrm{O}_{2}$ using peroxalate nanoparticles. (A) Peroxalate nanoparticle. (B) Chemiluminescence imaging. The figures were adapted from ref. [29] with permission. 
covering a whole small animal, but the resolution is at the millimeter level. The recent advances of bioluminescence and chemiluminescence probes enable whole animal studies of $\mathrm{H}_{2} \mathrm{O}_{2}$ production [29,30,47-49,55-57,62,102].

Figure 5 shows representative chemiluminescence images of global $\mathrm{H}_{2} \mathrm{O}_{2}$ production in a mouse model using Peroxalate nanoparticles [29]. $\mathrm{H}_{2} \mathrm{O}_{2}$ reacts with the peroxalate ester of (1) Peroxalate nanoparticles to produce a high-energy dioxetanedione intermediate within the nanoparticles (2), which then chemically excites the encapsulated dye, leading to light emission from the nanoparticles (3). Peroxalate nanoparticles were mixed with various concentrations of $\mathrm{H}_{2} \mathrm{O}_{2}$ and injected, intramuscularly, into the legs in Figure $5 \mathrm{~B}$. The concentration is (I) $10 \mu \mathrm{M} \mathrm{H}_{2} \mathrm{O}_{2}$, (II) $1 \mu \mathrm{M} \mathrm{H}_{2} \mathrm{O}_{2}$, (III) peroxalate nanoparticles only, and (IV) negative control. The chemi-/ bioluminescence imaging is the only technique for whole animal global $\mathrm{H}_{2} \mathrm{O}_{2}$ monitor in real time.

\section{Conclusion}

It is imperative to develop fluorescent probes that are able to monitor spatio-temporal intracellular $\mathrm{H}_{2} \mathrm{O}_{2}$ production in real time for live cells and in vivo studies. Among these fluorescent probes, chemoselective probes offer an attractive approach to $\mathrm{H}_{2} \mathrm{O}_{2}$ detection due to their general compatibility with an array of biological systems without external activating enzymes and genetic manipulation. Nanoprobes were recently developed for in vivo imaging of $\mathrm{H}_{2} \mathrm{O}_{2}$. A benefit arising from the multifunctional nanotechnology, probe is that it is designed for both chemiluminescence imaging and ratiometric imaging. Furthermore, genetic fluorescent probes that target redox sensitive proteins to specific cellular locations provide high sensitive targeted imaging technology for real time $\mathrm{H}_{2} \mathrm{O}_{2}$ imaging.

These emerging probes enable $\mathrm{H}_{2} \mathrm{O}_{2}$ detection using: 1) high resolution fluorescence imaging such as confocal microscopy and TPM; 2) large field of view global imaging involving in vivo chemi-/bioluminescence imaging; and 3) ratiometric imaging or FLIM for the quantification of cellular $\mathrm{H}_{2} \mathrm{O}_{2}$ levels.

\section{Abbreviations}

DCF: Dichlorofluorescein; FLIM: Fluorescence lifetime imaging microscopy; $\mathrm{H}_{2} \mathrm{O}_{2}$ : Hydrogen peroxide; NIR: Near-infrared; PEG: Polyethylene glycol; PET: Photoinduced electron transfer; ROI: Region of interest; ROS: Reactive oxygen species; SWNT: Single-walled carbon nanotube; TPM: Two-photon microscopy.

\section{Competing interests}

The authors declare that they have no competing interests.

\section{Authors' contributions}

HG, HA and REHL carried out the two-photon microscopy experiments and participated in manuscript preparation. BCD developed some of the chemoselective fluorescent probes and participated in manuscript preparation. All authors read and approved the final manuscript.

\section{Acknowledgement}

This work is supported by the National Institutes of Health (NIH) Grants 2P01AG014930. We acknowledge Chris Chang, Vivian S. Lin, and Yu Chen for helpful comments.

\section{Author details}

${ }^{1}$ Fischell Department of Bioengineering, University of Maryland, College Park, MD 20742, USA. ${ }^{2}$ Burke Medical Research Institute, Weill Medical College of Cornell University, White Plains, NY 10605, USA. ${ }^{3}$ Fishberg Department of Neuroscience, Friedman Brain Institute, Icahn School of Medicine at Mount Sinai, New York, NY 10029, USA. ${ }^{4}$ Department of Chemistry, The University of Chicago, Chicago, IL 60637, USA. ${ }^{5}$ School of Health and Natural Sciences, Mercy College, Dobbs Ferry, NY 10522, USA.

Received: 29 July 2014 Accepted: 6 October 2014 Published: 27 October 2014

\section{References}

1. Haskew-Layton RE, Payappilly JB, Smirnova NA, Ma TC, Chan KK, Murphy TH, Guo H, Langley B, Sultana R, Butterfield DA, Santagata S, Alldred MJ, Gazaryan IG, Bell GW, Ginsberg SD, Ratan RR: Controlled enzymatic production of astrocytic hydrogen peroxide protects neurons from oxidative stress via an Nrf2-independent pathway. Proc Natl Acad Sci U S A 2010, 107:17385-17390.

2. Dickinson BC, Peltier J, Stone D, Schaffer DV, Chang CJ: Nox2 redox signaling maintains essential cell populations in the brain. Nat Chem Biol 2011, 7:106-112

3. Miller EW, Tulyathan O, Isacoff EY, Chang CJ: Molecular imaging of hydrogen peroxide produced for cell signaling. Nat Chem Biol 2007, 3:263-267.

4. Dickinson BC, Chang CJ: Chemistry and biology of reactive oxygen species in signaling or stress responses. Nat Chem Biol 2011, 7:504-511.

5. Murphy MP, Holmgren A, Larsson NG, Halliwell B, Chang CJ, Kalyanaraman B, Rhee SG, Thornalley PJ, Partridge L, Gems D, Nystrom T, Belousov V, Schumacker PT, Winterbourn CC: Unraveling the biological roles of reactive oxygen species. Cell Metab 2011, 13:361-366.

6. Niethammer P, Grabher C, Look AT, Mitchison TJ: A tissue-scale gradient of hydrogen peroxide mediates rapid wound detection in zebrafish. Nature 2009, 459:996-999.

7. Rhee SG: H2O2, a necessary evil for cell signaling. Science 2006, 312:1882-1883.

8. Huang Y-Y, Chen AC-H, Arany PR, Hamblin MR: Role of Reactive Oxygen Species in Low Level Light Therapy. In Mechanisms for Low-Light Therapy IV. Edited by Waynant RW, Hamblin MR, Anders J. Proc. of SPIE 2009, 7165:716502.

9. Gough DR, Cotter TG: "Hydrogen Peroxide: A Jekyll and Hyde Signalling Molecule," Cell Death Dis 2. 2011

10. Rojkind M, Dominguez-Rosales JA, Nieto N, Greenwel P: Role of hydrogen peroxide and oxidative stress in healing responses. Cell Mol Life Sci 2002, 59:1872-1891.

11. Finkel T, Serrano M, Blasco MA: The common biology of cancer and ageing. Nature 2007, 448:767-774.

12. Balaban RS, Nemoto S, Finkel T: Mitochondria, oxidants, and aging. Cell 2005, 120:483-495.

13. Cutler RG: Oxidative stress and aging: catalase is a longevity determinant enzyme. Rejuv Res 2005, 8:138-140.

14. Finkel T, Holbrook NJ: Oxidants, oxidative stress and the biology of ageing. Nature 2000, 408:239-247.

15. Pi JB, Bai YS, Zhang Q, Wong V, Floering LM, Daniel K, Reece JM, Deeney JT, Andersen ME, Corkey BE, Collins S: Reactive oxygen species as a signal in glucose-stimulated insulin secretion. Diabetes 2007, 56:1783-1791.

16. Barnham KJ, Masters CL, Bush Al: Neurodegenerative diseases and oxidative stress. Nat Rev Drug Discov 2004, 3:205-214.

17. Lin MT, Beal MF: Alzheimer's APP mangles mitochondria. Nat Med 2006, 12:1241-1243.

18. Rao AV, Balachandran B: Role of oxidative stress and antioxidants in neurodegenerative diseases. Nutr Neurosci 2002, 5:291-309.

19. Essers MAG, Weijzen S, de Vries-Smits AMM, Saarloos I, de Ruiter ND, Bos JL, Burgering BMT: FOXO transcription factor activation by oxidative stress mediated by the small GTPase Ral and JNK. Embo J 2004, 23:4802-4812. 
20. Schreck R, Rieber P, Baeuerle PA: Reactive oxygen intermediates as apparently widely used messengers in the activation of the Nf-kappa-B transcription factor and Hiv-1. Embo J 1991, 10:2247-2258.

21. Schriner SE, Linford NJ, Martin GM, Treuting P, Ogburn CE, Emond M, Coskun PE, Ladiges W, Wolf N, Van Remmen H, Wallace DC, Rabinovitch PS: Extension of murine life span by overexpression of catalase targeted to mitochondria. Science 2005, 308:1909-1911.

22. Arnold RS, Shi J, Murad E, Whalen AM, Sun CQ, Polavarapu R, Parthasarathy S, Petros JA, Lambeth JD: Hydrogen peroxide mediates the cell growth and transformation caused by the mitogenic oxidase Nox1. Proc Natl Acad Sci U S A 2001, 98:5550-5555.

23. Wrona $M$, Patel KB, Wardman $P$ : The roles of thiol-derived radicals in the use of 2 ',7'-dichlorodihydrofluorescein as a probe for oxidative stress. Free Radical Bio Med 2008, 44:56-62.

24. Karlsson M, Kurz T, Brunk UT, Nilsson SE, Frennesson Cl: What does the commonly used DCF test for oxidative stress really show? Biochem J 2010, 428:183-190.

25. Guo HC, Aleyasin H, Howard SS, Dickinson BC, Lin VS, Haskew-Layton RE, $\mathrm{Xu}$ C, Chen Y, Ratan RR: Two-photon fluorescence imaging of intracellular hydrogen peroxide with chemoselective fluorescent probes. J Biomed Opt 2013, 18:106002.

26. Soh N: Recent advances in fluorescent probes for the detection of reactive oxygen species. Anal Bioanal Chem 2006, 386:532-543.

27. Woolley JF, Stanicka J, Cotter TG: Recent advances in reactive oxygen species measurement in biological systems. Trends Biochem Sci 2013, 38:556-565.

28. Chen Y, Guo H, Gong W, Qin L, Aleyasin H, Ratan RR, Cho S, Chen J, Xie S: Recent advances in two-photon imaging: technology developments and biomedical applications. Chin Opt Lett 2013, 11:011703.

29. Lee D, Khaja S, Velasquez-Castano JC, Dasari M, Sun C, Petros J, Taylor WR, Murthy N: In vivo imaging of hydrogen peroxide with chemiluminescent nanoparticles. Nat Mater 2007, 6:765-769.

30. Van de Bittner GC, Dubikovskaya EA, Bertozzi CR, Chang CJ: In vivo imaging of hydrogen peroxide production in a murine tumor model with a chemoselective bioluminescent reporter. Proc Natl Acad Sci U S A 2010, 107:21316-21321.

31. Miller EW, Albers AE, Pralle A, Isacoff EY, Chang CJ: Boronate-based fluorescent probes for imaging cellular hydrogen peroxide. J Am Chem Soc 2005, 127:16652-16659.

32. Yuan $L$, Lin WY, Xie YN, Chen B, Zhu SS: Single fluorescent probe responds to $\mathrm{H}_{2} \mathrm{O} 2$, NO, and $\mathrm{H} 2 \mathrm{O} 2 / \mathrm{NO}$ with three different sets of fluorescence signals. J Am Chem Soc 2012, 134:1305-1315.

33. Kumar M, Kumar N, Bhalla V, Sharma PR, Qurishi Y: A charge transfer assisted fluorescent probe for selective detection of hydrogen peroxide among different reactive oxygen species. Chem Commun 2012, 48:4719-4721.

34. Soh N, Sakawaki O, Makihara K, Odo Y, Fukaminato T, Kawai T, Irie M, Imato $\mathrm{T}$ : Design and development of a fluorescent probe for monitoring hydrogen peroxide using photoinduced electron transfer. Bioorgan Med Chem 2005, 13:1131-1139.

35. Srikun D, Miller EW, Dornaille DW, Chang CJ: An ICT-based approach to ratiometric fluorescence imaging of hydrogen peroxide produced in living cells. J Am Chem Soc 2008, 130:4596-4597.

36. Albers AE, Okreglak VS, Chang CJ: A FRET-based approach to ratiometric fluorescence detection of hydrogen peroxide. J Am Chem Soc 2006, 128:9640-9641.

37. Chang MCY, Pralle A, Isacoff EY, Chang CJ: A selective, cell-permeable optical probe for hydrogen peroxide in living cells. J Am Chem Soc 2004 126:15392-15393.

38. Dickinson BC, Huynh C, Chang CJ: A palette of fluorescent probes with varying emission colors for imaging hydrogen peroxide signaling in living cells. J Am Chem Soc 2010, 132:5906-5915.

39. Harris JM, Esain V, Frechette GM, Harris LJ, Cox AG, Cortes M, Garnaas MK, Carroll KJ, Cutting CC, Khan T, Elks PM, Renshaw SA, Dickinson BC, Chang CJ, Murphy MP, Paw BH, Vander Heiden MG, Goessling W, North TE: Glucose metabolism impacts the spatio-temporal onset and magnitude of HSC induction in vivo. Blood 2013, 121:2483-2493.

40. Abo M, Urano Y, Hanaoka K, Terai T, Komatsu T, Nagano T: Development of a highly sensitive fluorescence probe for hydrogen peroxide. J Am Chem Soc 2011, 133:10629-10637.

41. Miller EW, Bian SX, Chang CJ: A fluorescent sensor for imaging reversible redox cycles in living cells. J Am Chem Soc 2007, 129:3458-3459.
42. Dickinson $\mathrm{BC}$, Chang CJ: A targetable fluorescent probe for imaging hydrogen peroxide in the mitochondria of living cells. J Am Chem Soc 2008, 130:9638-9639.

43. Dickinson BC, Lin VS, Chang CJ: Preparation and use of MitoPY1 for imaging hydrogen peroxide in mitochondria of live cells. Nat Protoc 2013, 8:1249-1259.

44. Miller EW, Dickinson BC, Chang CJ: Aquaporin-3 mediates hydrogen peroxide uptake to regulate downstream intracellular signaling. Proc Natl Acad Sci U S A 2010, 107:15681-15686.

45. Dickinson BC, Tang Y, Chang ZY, Chang CJ: A nuclear-localized fluorescent hydrogen peroxide probe for monitoring sirtuin-mediated oxidative stress responses in vivo. Chem Biol 2011, 18:943-948.

46. Snyrychova I, Ayaydin F, Hideg E: Detecting hydrogen peroxide in leaves in vivo - a comparison of methods. Physiol Plantarum 2009, 135:1-18.

47. Schaferling M, Grogel DBM, Schreml S: Luminescent probes for detection and imaging of hydrogen peroxide. Microchim Acta 2011, 174:1-18.

48. Van de Bittner GC, Bertozzi CR, Chang CJ: Strategy for dual-analyte luciferin imaging: in vivo bioluminescence detection of hydrogen peroxide and caspase activity in a murine model of acute inflammation. J Am Chem Soc 2013, 135:1783-1795

49. Karton-Lifshin N, Segal E, Omer L, Portnoy M, Satchi-Fainaro R, Shabat D: A unique paradigm for a turn-ON near-infrared cyanine-based probe: noninvasive intravital optical imaging of hydrogen peroxide. J Am Chem Soc 2011, 133:10960-10965.

50. Chung C, Srikun D, Lim CS, Chang CJ, Cho BR: A two-photon fluorescent probe for ratiometric imaging of hydrogen peroxide in live tissue. Chem Commun 2011, 47:9618-9620.

51. Masanta G, Heo CH, Lim CS, Bae SK, Cho BR, Kim HM: A mitochondrialocalized two-photon fluorescent probe for ratiometric imaging of hydrogen peroxide in live tissue. Chem Commun 2012, 48:3518-3520.

52. Sikora A, Zielonka J, Lopez M, Joseph J, Kalyanaraman B: Direct oxidation of boronates by peroxynitrite: mechanism and implications in fluorescence imaging of peroxynitrite. Free Radical Bio Med 2009, 47:1401-1407.

53. Uusitalo LM, Hempel N: Recent advances in intracellular and in vivo ROS sensing: focus on nanoparticle and nanotube applications. Int J Mol Sci 2012, 13:10660-10679.

54. Kim G, Lee Y-EK, Kopelman R: Hydrogen Peroxide (H2O2) Detection With Nanoprobes for Biological Applications: A Mini-Review. In Oxidative Stress and Nanotechnology: Methods and Protocols, Methods in Molecular Biology. Edited by Armstrong D, Bharali DJ. New York: Humana Press; 2013:101-114

55. Lee I, Hwang O, Yoo D, Khang G, Lee D: Detection of hydrogen peroxide in vitro and in vivo using peroxalate chemiluminescent micelles. $B$ Korean Chem Soc 2011, 32:2187-2192.

56. Dasari M, Lee D, Erigala VR, Murthy N: Chemiluminescent PEG-PCL micelles for imaging hydrogen peroxide. J Biomed Mater Res A 2009, 89A:561-566.

57. Chen R, Zhang LZ, Gao J, Wu W, Hu Y, Jiang XQ: Chemiluminescent nanomicelles for imaging hydrogen peroxide and self-therapy in photodynamic therapy. J Biomed Biotechnol 2011, 2011:679492.

58. Shuhendler AJ, Pu K, Cui L, Uetrecht JP, Rao J: Real-time imaging of oxidative and nitrosative stress in the liver of live animals for drug-toxicity testing. Nat Biotechnol 2014, 32:373-380.

59. Jin H, Heller DA, Kalbacova M, Kim JH, Zhang JQ, Boghossian AA, Maheshri N, Strano MS: Detection of single-molecule $\mathrm{H} 2 \mathrm{O} 2$ signalling from epidermal growth factor receptor using fluorescent single-walled carbon nanotubes. Nat Nanotechnol 2010, 5:U302-U381.

60. Kim JH, Patra CR, Arkalgud JR, Boghossian AA, Zhang JQ, Han JH, Reuel NF, Ahn JH, Mukhopadhyay D, Strano MS: Single-molecule detection of $\mathrm{H}_{2} \mathrm{O} 2$ mediating angiogenic redox signaling on fluorescent single-walled carbon nanotube array. ACS Nano 2011, 5:7848-7857.

61. Heller DA, Jin H, Martinez BM, Patel D, Miller BM, Yeung TK, Jena PV, Hobartner C, Ha T, Silverman SK, Strano MS: Multimodal optical sensing and analyte specificity using single-walled carbon nanotubes. Nat Nanotechnol 2009, 4:114-120.

62. Lim CK, Lee YD, Na J, Oh JM, Her S, Kim K, Choi K, Kim S, Kwon IC: Chemiluminescence-generating nanoreactor formulation for near-infrared imaging of hydrogen peroxide and glucose level in vivo. Adv Funct Mater 2010, 20:2644-2648.

63. Tahir MN, Andre R, Sahoo JK, Jochum FD, Theato P, Natalio F, Berger R Branscheid R, Kolb U, Tremel W: Hydrogen peroxide sensors for 
cellular imaging based on horse radish peroxidase reconstituted on polymer-functionalized TiO2 nanorods. Nanoscale 2011, 3:3907-3914.

64. Kim G, Lee YEK, Xu H, Philbert MA, Kopelman R: Nanoencapsulation method for high selectivity sensing of hydrogen peroxide inside live cells. Anal Chem 2010, 82:2165-2169.

65. Kim SH, Kim B, Yadavalli VK, Pishko MV: Encapsulation of enzymes within polymer spheres to create optical nanosensors for oxidative stress. Anal Chem 2005, 77:6828-6833.

66. Wei $\mathrm{H}$, Wang E: Fe3O4 magnetic nanoparticles as peroxidase mimetics and their applications in $\mathrm{H} 2 \mathrm{O} 2$ and glucose detection. Anal Chem 2008, 80:2250-2254

67. Chang Q, Zhu LH, Jiang GD, Tang HQ: Sensitive fluorescent probes for determination of hydrogen peroxide and glucose based on enzyme-immobilized magnetite/silica nanoparticles. Anal Bioanal Chem 2009, 395:2377-2385.

68. Shiang YC, Huang CC, Chang HT: Gold nanodot-based luminescent sensor for the detection of hydrogen peroxide and glucose. Chem Commun 2009, 23:3437-3439

69. Li C, Wang S, Huang Y, Wen Q, Wang L, Kan Y: Photoluminescence properties of a novel cyclometalated iridium(iii) complex with coumarin-boronate and its recognition of hydrogen peroxide. Dalton Trans 2014, 43:5595-5602.

70. Malinouski M, Zhou Y, Belousov W, Hatfield DL, Gladyshev VN: Hydrogen peroxide probes directed to different cellular compartments. Plos One 2011, 6:e14564.

71. Belousov W, Fradkov AF, Lukyanov KA, Staroverov DB, Shakhbazov KS, Terskikh AV, Lukyanov S: Genetically encoded fluorescent indicator for intracellular hydrogen peroxide. Nat Methods 2006, 3:281-286.

72. Dooley CT, Dore TM, Hanson GT, Jackson WC, Remington SJ, Tsien RY: Imaging dynamic redox changes in mammalian cells with green fluorescent protein indicators. J Biol Chem 2004, 279:22284-22293.

73. Hanson GT, Aggeler R, Oglesbee D, Cannon M, Capaldi RA, Tsien RY, Remington SJ: Investigating mitochondrial redox potential with redox-sensitive green fluorescent protein indicators. J Biol Chem 2004, 279:13044-13053

74. Meyer AJ, Dick TP: Fluorescent protein-based redox probes. Antioxid Redox Sign 2010, 13:621-650

75. Wang XH, Fang HQ, Huang ZL, Shang W, Hou TT, Cheng AW, Cheng HP: Imaging ROS signaling in cells and animals. J Mol Med 2013, 91:917-927.

76. Lukyanov KA, Belousov W: Genetically encoded fluorescent redox sensors. Bba-Gen Subjects 2014, 1840:745-756.

77. Bilan DS, Pase L, Joosen L, Gorokhovatsky AY, Ermakova YG, Gadella TWJ, Grabher C, Schultz C, Lukyanov S, Belousov W: HyPer-3: a genetically encoded $\mathrm{H} 2 \mathrm{O} 2$ probe with improved performance for ratiometric and fluorescence lifetime imaging. ACS Chem Biol 2013, 8:535-542.

78. Gutsche M, Sobotta MC, Wabnitz GH, Ballikaya S, Meyer AJ, Samstag Y, Dick TP: Proximity-based protein thiol oxidation by $\mathrm{H} 2 \mathrm{O} 2$-scavenging peroxidases. J Biol Chem 2009, 284:31532-31540.

79. Albrecht SC, Barata AG, Grosshans J, Teleman AA, Dick TP: In vivo mapping of hydrogen peroxide and oxidized glutathione reveals chemical and regional specificity of redox homeostasis. Cell Metab 2011, 14:819-829.

80. Barata AG, Dick TP: "In vivo imaging of $\mathrm{H} 2 \mathrm{O} 2$ production in drosophila", hydrogen peroxide and cell signaling. Pt A 2013, 526:61-82.

81. Tormos KV, Chandel NS: Seeing the light: probing ROS in vivo using redox GFP. Cell Metab 2011, 14:720-721.

82. Jou MJ, Jou SB, Guo MJ, Wu HY, Peng Tl: Mitochondrial reactive oxygen species generation and calcium increase induced by visible light in astrocytes. Ann Ny Acad Sci 2004, 1011:45-56.

83. Konda VJ, Dickinson BC, Dougherty U, Mustafi R, Fichera A, Waxman I, Rajh $\mathrm{T}$, Chang $\mathrm{CJ}$, Bissonnette M: Novel hydrogen peroxide $\left(\mathrm{H}_{2} \mathrm{O} 2\right)$ sensing probe for in vivo cellular imaging in colorectal cancer. Gastroenterology 2011, 140:S128-S128.

84. Kobat $\mathrm{D}$, Horton $\mathrm{NG}, \mathrm{Xu}$ C: In vivo two-photon microscopy to 1.6-mm depth in mouse cortex. J Biomed Opt 2011, 16:106014.

85. Murari K, Zhang YY, Li SP, Chen YP, Li MJ, Li XD: Compensation-free, all-fiber-optic, two-photon endomicroscopy at $1.55 \mathrm{mu} \mathrm{m}$. Opt Lett 2011, 36:1299-1301.

86. Yazdanfar S, Joo C, Zhan C, Berezin MY, Akers WJ, Achilefu S: Multiphoton microscopy with near infrared contrast agents. J Biomed Opt 2010, 15:030505.

87. Yokoyama H, Tsubokawa H, Guo H, Shikata J, Sato K, Takashima K, Kashiwagi K, Saito N, Taniguchi H, Ito H: Two-photon bioimaging utilizing supercontinuum light generated by a high-peak-power picosecond semiconductor laser source. J Biomed Opt 2007, 12:054019.

88. Xu C, Wise FW: Recent advances in fibre lasers for nonlinear microscopy. Nat Photonics 2013, 7:875-882.

89. Reddy GD, Saggau P: Fast three-dimensional laser scanning scheme using acousto-optic deflectors. J Biomed Opt 2005, 10:064038.

90. Planchon TA, Gao L, Milkie DE, Davidson MW, Galbraith JA, Galbraith CG, Betzig E: Rapid three-dimensional isotropic imaging of living cells using Bessel beam plane illumination. Nat Methods 2011, 8:U417-U468.

91. Rivera DR, Brown CM, Ouzounov DG, Pavlova I, Kobat D, Webb WW, Xu C: Compact and flexible raster scanning multiphoton endoscope capable of imaging unstained tissue. Proc Natl Acad Sci U S A 2011, 108:17598-17603.

92. Hoy CL, Durr NJ, Chen PY, Piyawattanametha W, Ra H, Solgaard O, Ben-Yakar A: Miniaturized probe for femtosecond laser microsurgery and two-photon imaging. Opt Express 2008, 16:9996-10005.

93. Wu YC, Leng YX, Xi JF, Li XD: Scanning all-fiber-optic endomicroscopy system for 3D nonlinear optical imaging of biological tissues. Opt Express 2009, 17:7907-7915.

94. Swanson JA: Ratiometric fluorescence microscopy. Method Microbiol 2002, $31: 1-18$

95. Matlashov ME, Belousov W, Enikolopov G: How much $\mathrm{H} 2 \mathrm{O} 2$ is produced by recombinant $\mathrm{D}$-amino acid oxidase in mammalian cells? Antioxid Redox Sign 2014, 20:1039-1044

96. Mishina NM, Markvicheva KN, Bilan DS, Matlashov ME, Shirmanova MV Liebl D, Schultz C, Lukyanov S, Belousov W: Visualization of intracellular hydrogen peroxide with HyPer, a genetically encoded fluorescent probe. Method Enzymol 2013, 526:45-59.

97. Gadella TWJ, Jovin TM, Clegg RM: Fluorescence lifetime imaging microscopy (flim) - spatial-resolution of microstructures on the nanosecond time-scale. Biophys Chem 1993, 48:221-239.

98. Van Munster EB, Gadella TWJ: phi FLIM: a new method to avoid aliasing in frequency-domain fluorescence lifetime imaging microscopy. J Microsc-Oxford 2004, 213:29-38.

99. Pasini P, Musiani M, Russo C, Valenti P, Aicardi G, Crabtree JE, Baraldini M, Roda A: Chemiluminescence imaging in bioanalysis. J Pharmaceut Biomed 1998, 18:555-564.

100. Sato A, Klaunberg B, Tolwani R: In vivo bioluminescence imaging. Comparative Med 2004, 54:631-634.

101. Feng JC, Qin CH, Jia KB, Zhu SP, Yang X, Tian J: Bioluminescence tomography imaging in vivo: recent advances. leee J Sel Top Quant 2012, 18:1394-1402.

102. Lippert AR, Van de Bittner GC, Chang CJ: Boronate oxidation as a bioorthogonal reaction approach for studying the chemistry of hydrogen peroxide in living systems. Acc Chem Res 2011, 44:793-804.

doi:10.1186/2045-3701-4-64

Cite this article as: Guo et al: Recent advances in hydrogen peroxide imaging for biological applications. Cell \& Bioscience 2014 4:64.

\section{Submit your next manuscript to BioMed Central and take full advantage of:}

- Convenient online submission

- Thorough peer review

- No space constraints or color figure charges

- Immediate publication on acceptance

- Inclusion in PubMed, CAS, Scopus and Google Scholar

- Research which is freely available for redistribution 